\title{
Systematic Review and Pooled Analyses of Recent Neurointerventional Randomized Controlled Trials: Setting a New Standard of Care for Acute Ischemic Stroke Treatment after 20 Years
}

\author{
Mohammed Hussain $^{a} \quad$ Mohammad Moussavi $^{a} \quad$ Daniel Korya ${ }^{a}$ \\ Siddhart Mehta ${ }^{a}$ Jaskiran Brar ${ }^{a}$ Harina Chahal $^{a}$ Ihtesham Qureshi ${ }^{a}$ \\ Tapan Mehta $^{b}$ Javaad Ahmad ${ }^{a}$ Osama O. Zaidat ${ }^{c}$ Jawad F. Kirmani ${ }^{a}$ \\ a Stroke and Neurovascular Center, JFK Medical Center, Edison, N.J., b Department of \\ Neurology, Hartford Hospital, University of Connecticut, Hartford, Conn., and 'Department \\ of Neurology, Medical College of Wisconsin, Milwaukee, Wis., USA
}

\section{Key Words}

Pooled analysis - Embolectomy · Neurointervention - Ischemic stroke - Endovascular therapy · Intra-arterial intervention $\cdot$ Randomized controlled trials

\begin{abstract}
Background: Recent advances in the treatment of ischemic stroke have focused on revascularization and led to better clinical and functional outcomes. A systematic review and pooled analyses of 6 recent multicentered prospective randomized controlled trials (MPRCT) were performed to compare intravenous tissue plasminogen activator (IV tPA) and endovascular therapy (intervention) with IV tPA alone (control) for anterior circulation ischemic stroke (AIS) secondary to large vessel occlusion (LVO). Objectives: Six MPRCTs (MR CLEAN, ESCAPE, EXTEND IA, SWIFT PRIME, REVASCAT and THERAPY) incorporating image-based LVO AIS were selected for assessing the following: (1) prespecified primary clinical outcomes of AIS patients in intervention and control arms: good outcomes were defined by a modified Rankin Scale score of $0-2$ at 90 days; (2) secondary clinical outcomes were: (a) revascularization rates [favorable outcomes defined as modified Thrombolysis in Cerebral Infarction scale (mTICI) score of 2b/3]; (b) symptomatic intracranial hemorrhage (sICH) rates and mortality; (c) derivation of number needed to harm (NNH), number needed to treat (NNT), and relative percent
\end{abstract}

M.M. and D.K. have contributed equally to this work. 
difference (RPD) between intervention and control groups, and (d) random effects model to determine overall significance (forest and funnel plots). Results: A total of 1,386 patients were included. Good outcomes at 90 days were seen in $46 \%$ of patients in the intervention ( $p<$ $0.00001)$ and in $27 \%$ of patients in the control groups ( $<$-0.00002). An mTICI score of $2 b / 3$ was achieved in $70.2 \%$ of patients in the intervention arm. The sICH and mortality in the intervention arm compared with the control arm were 4.7 and $14.3 \%$ versus 7.9 and $17.8 \%$, respectively. The NNT and NNH in the intervention and control groups were 5.3 and 9.1, respectively. Patients in the intervention arm had a 50.1\% (RPD) better chance of achieving a good 90-day outcome as compared to controls. Conclusions: Endovascular therapy combined with IV tPA (in appropriately selected patients) for LVO-related AIS is superior to IV tPA alone. These results support establishing an endovascular therapy in addition to IV tPA as the standard of care for AIS secondary to LVO.

(C) 2016 S. Karger AG, Basel

\section{Background}

Reperfusion therapy aiming to achieve recanalization of acutely occluded vessels has been a consistent objective in the setting of arterial ischemia for both cardiac and cerebral pathologies [1]. The world of cardiology and, in particular, interventional cardiology underwent a renaissance period with a major shift in the treatment paradigm consisting of a transition from intravenous (IV) thrombolytic treatments to percutaneous coronary intervention (PCI) in the early 1990s [2,3]. Considerable enthusiasm with treatment protocol establishment was generated by meta-analyses such as the one done by Weaver et al. [4, 5] in 1997, showing that primary PCI was superior to immediate thrombolysis in acute myocardial infarction. The ischemic stroke and, in particular, the intra-arterial treatment field is undergoing a renaissance period in its own right with a change in paradigm [6]. The past decade has ushered in a series of multicenter prospective randomized controlled trials (MPRCTs) that evaluated the efficacy and safety of endovascular anterior circulation ischemic stroke (AIS) therapy. However, to date, the application of endovascular AIS therapies has not received FDA approval [7]. This is in part related to the relatively equivocal results that were observed in previous studies comparing endovascular treatment with IV tissue plasminogen activator (IV tPA) in AIS [8]. As a result, IV tPA administered within $3 \mathrm{~h}$ of symptom onset is the only FDA-approved therapy for best medical management of acute ischemic strokes [7]. Nevertheless these past studies did shed light on factors that would eventually translate into optimal patient outcomes. These included the application of imaging modalities to confirm large vessel occlusions (LVOs) as well as to exclude patients with a large infarct core and the need for faster door-to-revascularization times [6]. The previous trials also aided in determining the efficacy of the newer generation devices and provided a basis for future trial designs [8].

The aforementioned learning points were taken into account by the 6 most recent MPRCTs: MR CLEAN, ESCAPE, EXTEND IA, SWIFT PRIME, REVASCAT and THERAPY [9-14]. These trials tested the following hypothesis: when compared to IV tPA alone, the addition of endovascular therapy (stent retriever and/or clot suction technology) combined with appropriate patient selection (image-based selection of LVO in anterior circulation, small- to moderate-sized infarct core and significantly salvageable brain tissue) will achieve better patient outcomes, lower rates of both futile procedures and mortality. We sought to perform a review and pooled analyses of results from the 6 most recent MPRCTs. Outcomes were measured with level of functional independence as defined by the modified Ranking Scale (mRS) at 90 days between the control (IV tPA) and interventional groups (endovascular plus IV tPA, when applicable). 


\section{Materials and Methods}

Search Methods Used

To access data sets and information pertaining to the MPRCTs we used a combination of PubMed, Cochrane Central register of controlled trials, data gathered from the International Stroke Conference in Nashville, Tenn., USA (2015) and from the European Stroke Organization Conference in Glasgow, UK (2015). The study was conducted from February 11 until March 10, 2015. Studies that were published in the New England Journal of Medicine between January and June 2015 were selected for review. A full report of the majority of those studies in addition to supplementary files was subsequently retrieved. Data on patient selection, inclusion and exclusion criteria, types of endovascular devices used, outcome in terms of mRS score, recanalization rates [modified Thrombolysis in Cerebral Infarction scale (mTICI)/TICI scores], symptomatic intracranial hemorrhage rates $(\mathrm{sICH})$ and mortality were gathered from each study done independently.

The Cochrane method of analysis was used to judge the strength of the study and reliability of the results as well as potential bias. Our study was also registered under the PROSPERO International Prospective Register for Systemic Reviews (Pending Registration Number).

Inclusion Criteria

The trials included met the following criteria: (1) multicenter, prospective and randomized; (2) comparison of endovascular therapy with stent retriever and/or clot suction technology with IV tPA (if eligible); (3) availability of 90-day mRS follow-up data in patients undergoing endovascular therapy with IV tPA, when applicable compared to IV tPA alone; (4) available rate of successful recanalization: standard or modified TICI score of $2 \mathrm{~b} / 3$ or mTICI score of $2 \mathrm{~b} / 3$ in the endovascular arm; (5) available rate of sICH and death; (6) patient age of at least 18 years or above; (7) time of symptom onset less than $12 \mathrm{~h}$; (8) use of imaging modalities [CT angiography, CT-derived Alberta Stroke Program Early Computed Tomography Score (ASPECTS) score, CT perfusion] to determine LVO in anterior circulation, and mild to moderate size of core infarction; (9) presence of significantly salvageable brain tissue based on clinical and/or imaging information, and (10) studies that were published in the New England Journal of Medicine from January to June 2015.

Exclusion Criteria

We did not include trials with the following characteristics: (1) single center and nonrandomized; (2) predominant use of old-generation endovascular devices; (3) no head-to-head comparison of endovascular device outcome with IV tPA; (4) failure to report recanalization rates; (5) failure to use imaging modalities in confirming the presence of LVO in anterior circulation, patients with large-degree ischemic change (demonstrated on CT scan with $>2 / 3$ middle cerebral artery distribution changes, ASPECTS $<6$, CT perfusion core $>70 \mathrm{ml}$ ), and (6) time of symptom onset more than $12 \mathrm{~h}$.

\section{Outcome Measures}

Measures used for the final analysis were subdivided into primary and secondary outcomes. The primary clinical outcome measure was improvement in the mRS score at 90 days. The mRS scoring system ranges from 0 to 6 (stratification of values: 0 , no symptoms at all; 1 , no major disability; 2 , slight disability; 3 , moderate disability requiring some help but able to walk without assistance; 4, moderately severe disability; 5 , severe disability, and 6, death) [1, 2]. The mRS scores were obtained at 90 days following enrollment and analyzed in patients who received current standard of care (IV tPA alone) versus those who received IV tPA (when eligible) and endovascular therapy. Secondary outcome measures were desirable recanalization rates defined as standard TICI or mTICI score of $2 b / 3$, sICH rate, all-cause mortality, number needed to treat (NNT) and number needed to do harm (NNH).

\section{Statistical Analysis}

A biostatistician performed all analyses. SPSS version 22 was used to derive means and standard deviation for continuous variables and percentages for categorical variables. The independent-samples t test was used to compare means between three groups of mRS scores (0-2,3-4 and 5-6), between trials, as continuous variables from the interventional and control arms of each trial. Categorical variables were compared using $\chi^{2}$ testing. A p value of $<0.05$ was considered significant. Forest plots were created to graphically display the summary effect of the meta-analysis. Furthermore, a random effects model was used to create the graphs. 
Table 1. Demographic profile of the 6 studies

\begin{tabular}{|c|c|c|c|c|c|c|c|c|c|}
\hline Trial & $\begin{array}{l}\text { Age, } \\
\text { years }\end{array}$ & $\begin{array}{l}\text { Symptom } \\
\text { onset, } \mathrm{h}\end{array}$ & $\begin{array}{l}\text { NIHSS } \\
\text { score }\end{array}$ & $\begin{array}{l}\text { Baseline } \\
\text { function }\end{array}$ & Imaging & Control & Intervention & Device & $\begin{array}{l}\text { Primary } \\
\text { end point }\end{array}$ \\
\hline MR CLEAN & $\geq 18$ & $<6$ & $\geq 2$ & $\begin{array}{l}96 \% \text { of patients } \\
\text { had an } \mathrm{mRS} \\
\text { score } 0-2\end{array}$ & $\begin{array}{l}\text { CT } \\
\text { (no ASPECTS) } \\
\text { and CTA }\end{array}$ & $\begin{array}{l}\text { IV tPA if } \\
\text { qualified }\end{array}$ & $\begin{array}{l}\text { IA thrombectomy + } \\
\text { IV tPA if qualified }\end{array}$ & $\begin{array}{l}\text { stent } \\
\text { retrievers }\end{array}$ & $\begin{array}{l}\text { mRS score at } \\
90 \text { days }\end{array}$ \\
\hline ESCAPE & $\geq 18$ & $<12$ & disabling & $\begin{array}{l}\text { Barthel index } \\
\geq 90\end{array}$ & $\begin{array}{l}\text { CT } \\
\text { (ASPECTS } \geq 6 \text { ) } \\
\text { and CTA }\end{array}$ & $\begin{array}{l}\text { IV tPA if } \\
\text { qualified }\end{array}$ & $\begin{array}{l}\text { IA thrombectomy + } \\
\text { IV tPA if qualified }\end{array}$ & $\begin{array}{l}\text { stent } \\
\text { retrievers }\end{array}$ & $\begin{array}{l}\mathrm{mRS} \text { score at } \\
90 \text { days }\end{array}$ \\
\hline EXTEND IA & $\geq 18$ & $<4.5$ & no limit & mRS score $<2$ & $\begin{array}{l}\text { CT and CT } \\
\text { perfusion } \\
\text { (core } \leq 70 \mathrm{ml} \\
\text { and mismatch } \\
\text { ratio }>1.2\end{array}$ & IV tPA & $\begin{array}{l}\text { IA thrombectomy + } \\
\text { IV tPA }\end{array}$ & $\begin{array}{l}\text { stent } \\
\text { retrievers }\end{array}$ & $\begin{array}{l}\mathrm{mRS} \text { score at } \\
90 \text { days }\end{array}$ \\
\hline $\begin{array}{l}\text { SWIFT } \\
\text { PRIME }\end{array}$ & $18-80$ & $<4.5$ & $8-29$ & mRS score $\leq 1$ & $\begin{array}{l}\text { CT } \\
\text { (ASPECTS } \geq 6 \text { ) } \\
\text { and CTA }\end{array}$ & IV tPA & $\begin{array}{l}\text { IA thrombectomy + } \\
\text { IV tPA }\end{array}$ & $\begin{array}{l}\text { stent } \\
\text { retrievers }\end{array}$ & $\begin{array}{l}\text { reperfusion at } \\
24 \mathrm{~h} \text { and early } \\
\text { neurologic } \\
\text { improvement }\end{array}$ \\
\hline REVASCAT & $18-85$ & $<8$ & $\geq 6$ & mRS score $\leq 1$ & $\begin{array}{l}\text { CT } \\
\text { (ASPECTS } \geq 8 \text { ) } \\
\text { and CTA }\end{array}$ & IV tPA & $\begin{array}{l}\text { IA thrombectomy + } \\
\text { IV tPA }\end{array}$ & $\begin{array}{l}\text { Solitaire } \\
\text { FR stent } \\
\text { retriever }\end{array}$ & $\begin{array}{l}\text { mRS score at } \\
90 \text { days }\end{array}$ \\
\hline THERAPY & $18-85$ & $<4.5$ & $\geq 8$ & mRS score $<2$ & $\begin{array}{l}\text { CT (ASPECTS, } \\
\text { clot length) } \\
\text { and CTA }\end{array}$ & IV tPA & $\begin{array}{l}\text { IA thrombectomy + } \\
\text { IV tPA }\end{array}$ & $\begin{array}{l}\text { Penumbra } \\
\text { suction } \\
\text { (Separator, } \\
\text { Separator 3D, } \\
\text { ACE, other) }\end{array}$ & $\begin{array}{l}\text { mRS score at } \\
90 \text { days }\end{array}$ \\
\hline
\end{tabular}

CTA = CT angiography. Age, symptom onset, NIHSS score, prestroke functioning and imaging criteria were gathered for the 6 MPRCTs, as well as the type of intervention and primary end point in the endovascular arm versus control arm of the included MPRCTs: all except EXTEND IA used mRS score at 90 days as primary end point. EXTEND IA used early neurological improvement and reperfusion at $24 \mathrm{~h}$ as primary end point.

The Review Manager (RevMan 5.2) statistical software was used to create the forest plot. An odds ratio (OR) was used to measure the effect and plotted on a log scale; a vertical line drawn at an OR value of 1.0 represents 'no effect'. A confidence interval overlapping the vertical line of 'no effect' represented a lack of statistically significant effect. For assessing heterogeneity, the $\mathrm{Q}$ statistical value $\mathrm{I}^{2}$ was used to interpret the proportion of the existing variability due to heterogeneity between studies. Funnel plots were created to graphically represent the existence of publication bias.

\section{Results}

\section{Highlights of Search Results}

Our search result yielded 6 recent trials that were multicentered, prospectively randomized controlled trials: MR CLEAN, ESCAPE, EXTEND IA, SWIFT PRIME, REVASCAT and THERAPY [9-14]. During the time period between January and April 2015, there were no other studies deemed eligible other than the aforementioned 6 trials. A total of 1,386 patients were included in the 6 studies of which 688 patients were randomized into endovascular treatment in addition to IV tPA (intervention), and 698 we randomized into IV tPA alone (control). At baseline, all participants were functioning independently (mRS score $0-2$ ). The characteristics of the control group and intervention group were matched. Table 1 provides a highlight of the demographic patterns observed in the 6 trials.

All the trials, with the exception of EXTEND IA and MR CLEAN, used the ASPECTS ranging from 0 to 10, with 1 point subtracted for any evidence of early ischemic change in each defined region on the CT scan $[15,16]$. EXTEND IA used CT perfusion as the imaging modality for inclusion criteria; the median ischemic core volume was $12 \mathrm{ml}$ (endovascular group) and 18 $\mathrm{ml}$ (control group). 
Hussain et al.: Systematic Review and Pooled Analyses of Recent Neurointerventional Randomized Controlled Trials

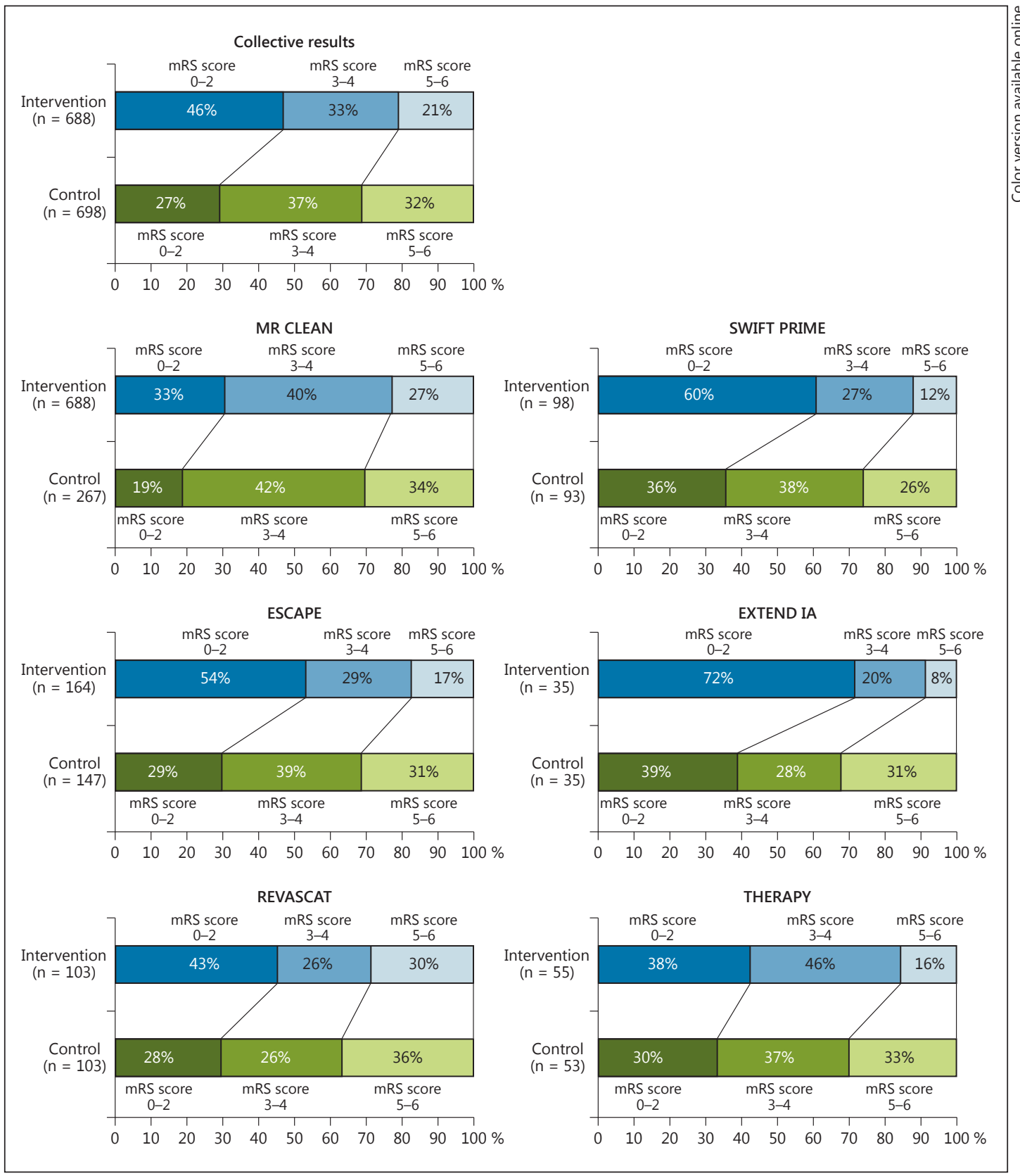

Fig. 1. Bar graph representation of the 6 MPRCTs analyzed with mRS breakdown between the intervention group versus controls as composite and individual results.

Treatment modalities were consistent within the trials. The intervention arm mainly received a combination of intra-arterial thrombectomy using stent retrievers (in 5/6 trials) or Penumbra suctioning device (THERAPY) and IV tPA (in eligible patients). The control arm received IV tPA alone, if the patients were within the prespecified therapeutic time window from symptom onset up to $4.5 \mathrm{~h}$. Furthermore, the prespecified primary end point was the mRS score at 90 days for MR CLEAN, ESCAPE, SWIFT, REVASCAT and THERAPY. The primary end point set by EXTEND IA was reperfusion at $24 \mathrm{~h}$ and early neurologic improvement (table 1). 

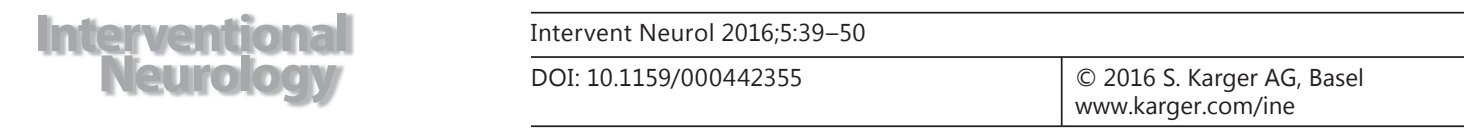

Hussain et al:: Systematic Review and Pooled Analyses of Recent Neurointerventional Randomized Controlled Trials

\begin{tabular}{|c|c|c|c|c|c|c|c|c|c|c|}
\hline \multirow{3}{*}{$\begin{array}{l}\text { Study or } \\
\text { subgroup }\end{array}$} & \multicolumn{2}{|c|}{$\begin{array}{l}\text { Medical } \\
\text { treatment }\end{array}$} & \multicolumn{2}{|c|}{$\begin{array}{l}\text { Endovascular } \\
\text { treatment }\end{array}$} & \multirow{3}{*}{$\begin{array}{l}\text { Weight, } \\
\% \\
26.6\end{array}$} & \multirow{3}{*}{$\begin{array}{c}\text { OR } \\
\text { M-H, fixed, 95\% CI } \\
0.35[0.22,0.56]\end{array}$} & \multirow{2}{*}{\multicolumn{4}{|c|}{$\begin{array}{c}\text { OR } \\
\mathrm{M}-\mathrm{H}, \text { fixed, } 95 \% \mathrm{CI}\end{array}$}} \\
\hline & \multirow{2}{*}{$\begin{array}{c}\text { events } \\
43\end{array}$} & \multirow{2}{*}{$\begin{array}{l}\text { total } \\
147\end{array}$} & \multirow{2}{*}{$\begin{array}{c}\text { events } \\
89\end{array}$} & \multirow{2}{*}{$\begin{array}{l}\text { total } \\
164\end{array}$} & & & & & & \\
\hline & & & & & & & & - & & \\
\hline EXTEND IA & 14 & 35 & 25 & 35 & 6.7 & $0.27[0.10,0.72]$ & & & & \\
\hline MR CLEAN & 51 & 267 & 77 & 233 & 29.7 & $0.48[0.32,0.72]$ & & $\longrightarrow-$ & & \\
\hline REVASCAT & 29 & 103 & 44 & 103 & 14.1 & $0.53[0.29,0.94]$ & & & & \\
\hline SWIFT PRIME & 33 & 93 & 59 & 98 & 16.5 & $0.38[0.20,0.85]$ & & - & & \\
\hline THERAPY & 16 & 53 & 21 & 55 & 8.4 & $0.70[0.31,1.56]$ & & & & \\
\hline Total (95\% CI) & & 698 & & 688 & 100.0 & $0.43[0.34,0.54]$ & & 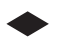 & & \\
\hline Total events & \multicolumn{2}{|l|}{186} & \multicolumn{2}{|l|}{315} & & & & & & \\
\hline \multicolumn{7}{|c|}{ Heterogeneity: $\chi^{2}=4.11$, d.f. $=5(p=0.53) ; I^{2}=0 \%$} & $\begin{array}{ll}1 & 1 \\
0.1 & 0.2\end{array}$ & 0.5 & $\begin{array}{ll}1 & 1 \\
1 & 2\end{array}$ & $\begin{array}{ll}1 & 1 \\
5 & 10\end{array}$ \\
\hline \multicolumn{7}{|c|}{ Test for overall effect: $Z=7.19(p<0.00001)$} & $\begin{array}{r}\text { Endovasc } \\
\text { medical tr } \\
\text { bett }\end{array}$ & $\begin{array}{l}\mathrm{a} \\
\text { arment }\end{array}$ & $\begin{array}{r}\text { Medicalt } \\
\text { inclu }\end{array}$ & $\begin{array}{l}\text { ment alone } \\
\text { g IV tPA } \\
\text { ter }\end{array}$ \\
\hline
\end{tabular}

Fig. 2. Forest plot representing a random effects model for the meta-analysis of good outcome (mRS score $0-2)$ among the individual 6 MPRCTs.

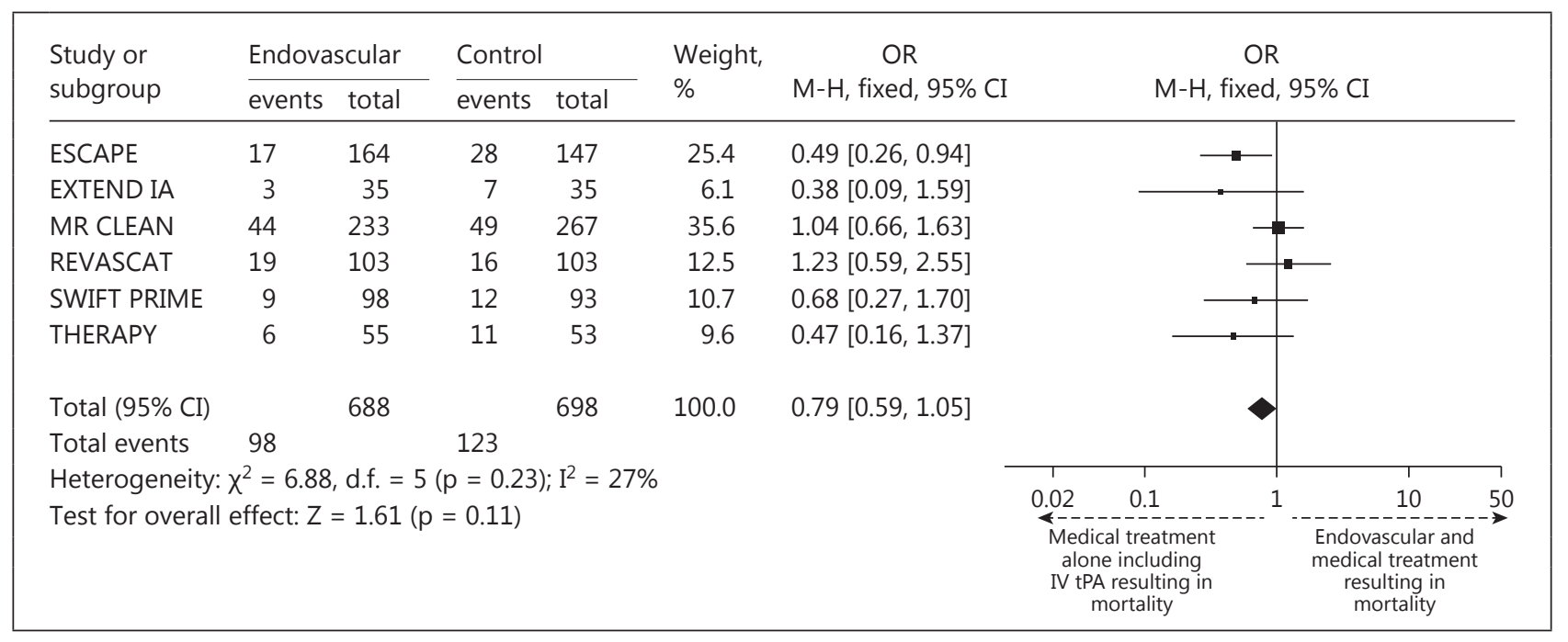

Fig. 3. Forest plot representation of mortality among all 6 MPRCTs.

The pooled results of the primary end point showed that $46 \%$ of patients in the intervention arm achieved an mRS score of $0-2$ at 90 days after treatment, compared to only $27 \%$ in controls (fig. 1). The individual studies that made up the pooled analyses along with their respective results separated by mRS scores of $0-2,3-4$ and 5-6 are shown in figure 1. Forest and funnel plots were constructed to show the relative strength of treatment effects across the 6 MPRCTs with an mRS stratification between 0-2, 3-4, 5-6 and mortality (fig. 2-4).

Figure 6 demonstrates that for every 5.3 patients treated with endovascular therapy along with IV tPA, 1 will become independent at 90 days as compared with IV tPA alone (NNT for endovascular $=5.3$ ). Furthermore, for every 9.1 patients eligible for endovascular treatment who receive IV tPA alone, 1 will be dead or disabled at 90 days (NNH for IV tPA alone $=9.1$. 


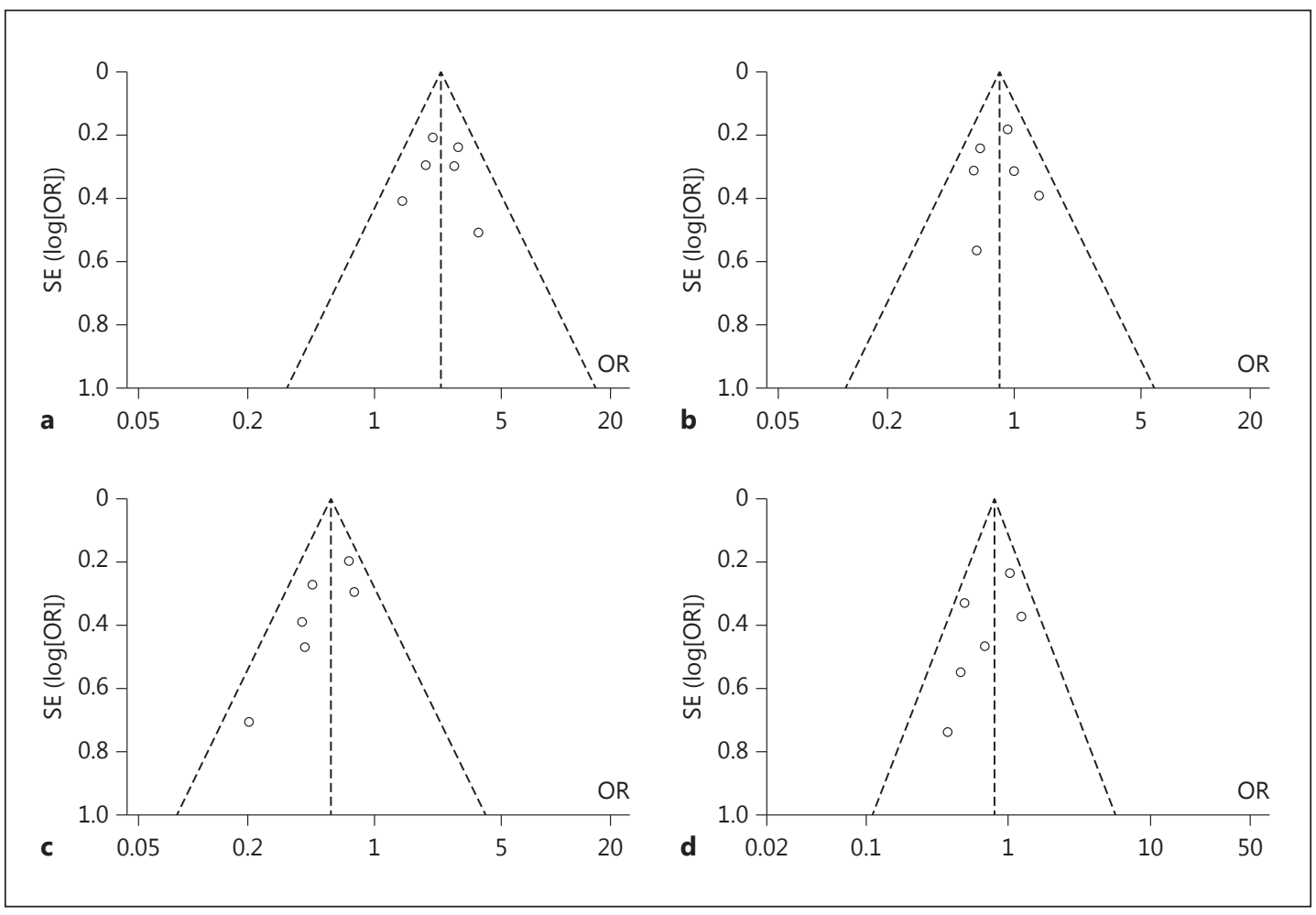

Fig. 4. Funnel plot representation of the 6 MPRCTs with mRS stratification. Funnel plots demonstrating lack of heterogeneity or bias between trials looking at good outcome, i.e. mRS score of 0-2 (a), mRS score of 3-4 (b), poor outcome, i.e. mRS score of 5-6 (c), and mortality (d).

Table 2. Number and percentage of patients achieving desired rates of recanalization: $\mathrm{mTICI}$ score $2 \mathrm{~b} / 3$ enrolled in the 6 MPRCTs

\begin{tabular}{lcll}
\hline Trial & $\begin{array}{l}\text { Total } \\
\text { patients }\end{array}$ & $\begin{array}{l}\text { Number of } \\
\text { patients who } \\
\text { achieved } \\
\text { mTICI 2b/3 }\end{array}$ & $\begin{array}{l}\text { Percentage of } \\
\text { patients who } \\
\text { achieved mTICI } \\
2 \mathrm{~b} / 3\end{array}$ \\
\hline SWIFT & 83 & 73 & 88 \\
ESCAPE & 156 & $113^{\mathrm{a}}$ & $72^{\mathrm{a}}$ \\
MR CLEAN & 196 & 115 & 59 \\
EXTEND IA & 29 & 25 & 86 \\
REVASCAT & 103 & 67 & 66 \\
THERAPY & 50 & 37 & 73 \\
Combined & 464 & 326 & 70.2 \\
\hline
\end{tabular}

a Utilized TICI $2 \mathrm{~b} / 3$, not mTICI $2 \mathrm{~b} / 3$.

The mTICI scores of $2 \mathrm{~b} / 3$ were available for the group of patients that underwent endovascular recanalization (except ESCAPE, which had TICI scores of $2 b / 3$ ), which showed an average of $70.2 \%$ rate of recanalization (table 2). The mortality rate in the intervention arm was $14.3 \%$, while the mortality rate of the control arm was $17.8 \%$ (fig. 1). The sICH rate was $4.7 \%$ in the intervention arm compared to $7.9 \%$ in controls (fig. 2; table 3). The relative percent difference (RPD) was calculated to be $50.1 \%$ between patients in the intervention and control arms with regard to achieving an mRS of $0-2$ at 90 days, i.e., patients in the inter- 
Fig. 5. NNT and NNH with RPD comparison between endovascular plus IV tPA versus best medical management (including use of IV tPA).

Table 3. sICH rate across the trials: treatment versus control arms
C) 2016 S. Karger AG, Basel www.karger.com/ine

Hussain et al.: Systematic Review and Pooled Analyses of Recent Neurointerventional Randomized Controlled Trials

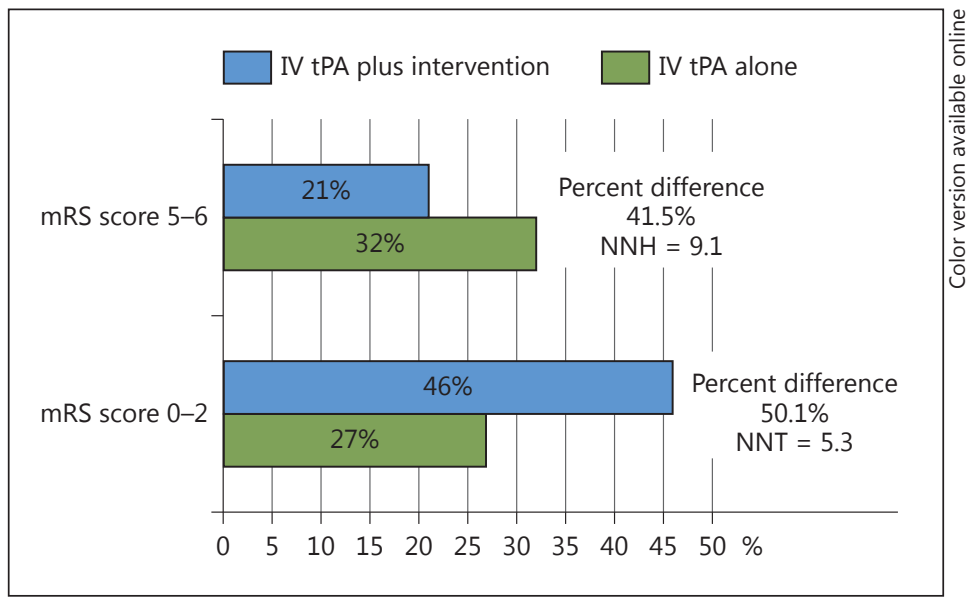

\begin{tabular}{llrrc}
\hline Trial & & Total & sICH, $\mathrm{n}$ & sICH, $\%$ \\
\hline \multirow{2}{*}{ SWIFT PRIME } & Endovascular arm & 97 & 1 & 1 \\
& Control arm & 98 & 3 & 3 \\
\hline ESCAPE & Endovascular arm & 165 & 6 & 4 \\
& Control arm & 150 & 4 & 3 \\
\hline MR CLEAN & Endovascular arm & 233 & 18 & 8 \\
& Control arm & 267 & 17 & 6 \\
\hline EXTEND IA & Endovascular arm & 35 & 0 & 0 \\
& Control arm & 35 & 2 & 6 \\
\hline REVASCAT & Endovascular arm & 103 & 2 & 1.9 \\
& Control arm & 103 & 2 & 1.9 \\
\hline THERAPY & Endovascular arm & 55 & 6 & 10.9 \\
& Control arm & 53 & 28 & 11.3 \\
\hline Combined & Endovascular arm & 688 & 33 & 4.7 \\
& Control arm & 706 & 56 & 7.9 \\
\hline
\end{tabular}

vention arm were $50.1 \%$ more likely to be independent at 90 days compared with controls. Patients who did not receive intervention along with IV tPA were $41.5 \%$ more likely to be dead or disabled at 90 days (RPD of $41.5 \%$ for an mRS score of 5-6 at 90 days).

\section{Discussion}

The past decade brought with it a dynamic treatment model for AIS that has been in constant evolution with learning points gathered after every major trial to restructure it further toward achieving better patient outcomes. From the FDA approval of IV tPA in 1995 to the 2015 announcement of the latest MPRCT, enough data has accrued in the literature to reiterate the importance of achieving faster and higher rates of recanalization in appropriately selected patients. This has correlated with better patient outcomes, with lower rates of morbidity and mortality [3, 16, 19-24].

These pooled analyses demonstrated several important advantages associated with the addition of endovascular therapy to IV tPA. Primarily, patients were twice as likely to be independent and over $40 \%$ less likely to be dead or disabled at 90 days if they were treated with endovascular therapy along with IV tPA. Furthermore, this benefit was estimated to be 
Hussain et al.: Systematic Review and Pooled Analyses of Recent Neurointerventional Randomized Controlled Trials

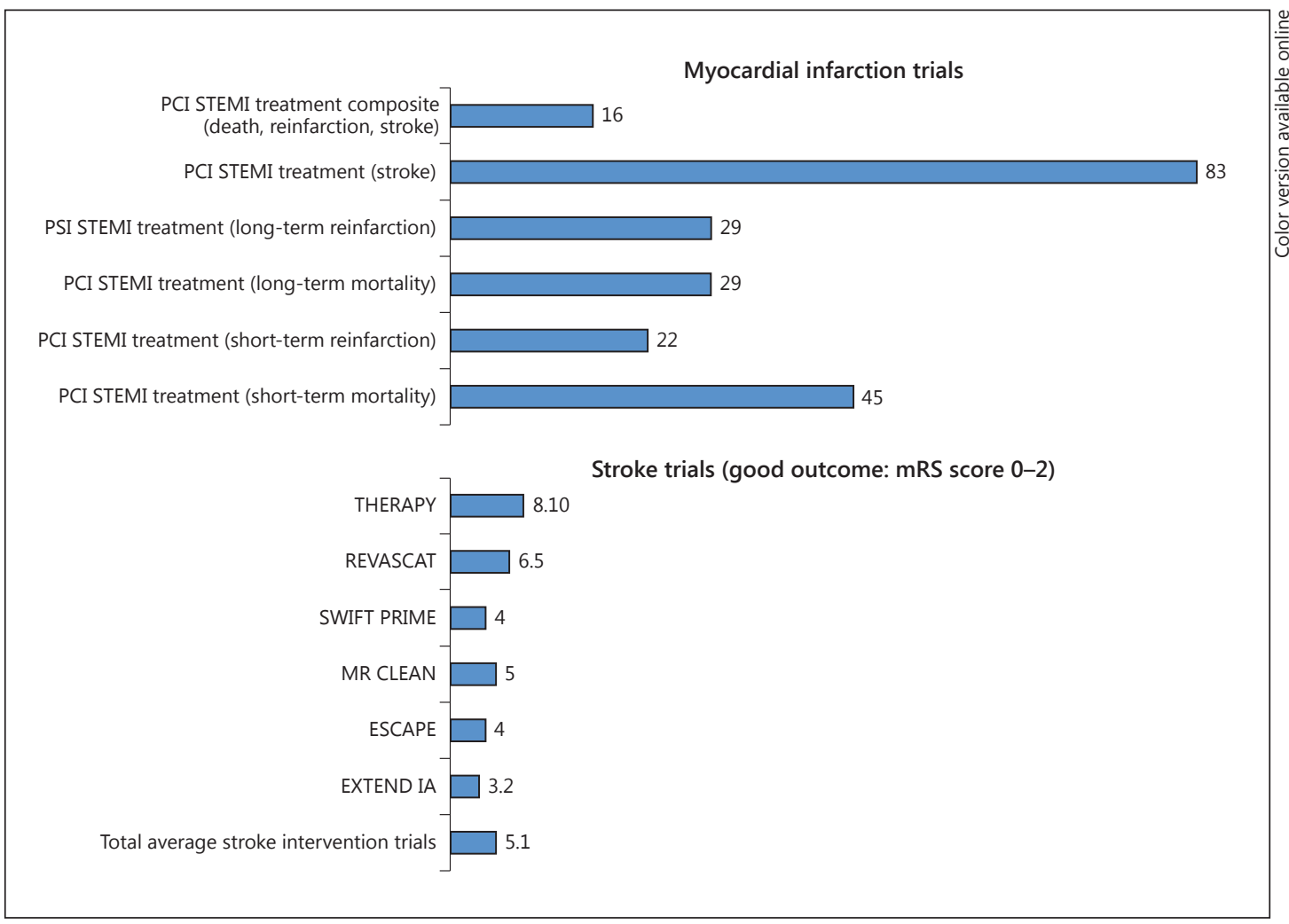

Fig. 6. Bar graph representation of NNT in PCI for STEMI (stratified as composite score: death, myocardial reinfarction and stroke) [11], PCI for STEMI treatment to avoid stroke, PCI for STEMI to prevent long-term reinfarction, PCI for STEMI treatment to avoid long-term mortality, PCI for STEMI treatment to avoid shortterm reinfarction, PCI for STEMI treatment to avoid short-term mortality [12], versus NNT for stroke endovascular treatment with best medical management to attain a 90-day mRS score of 0-2 (functional independence) in the 6 MPRCTs with composite average.

frequently achieved since it was shown that by adding endovascular therapy to IV tPA, 1 out of every 5.1 patients was independent at 90 days. Conversely, for every 9 eligible patients that endovascular therapy was not offered to, 1 was left dead or disabled. This was in stark contrast to the relatively higher NNT value of 16 for PCI application in ST elevation myocardial infarction (STEMI) to prevent death, reinfarction and stroke $[17,18]$. Furthermore, the NNT values for PCI-treated STEMIs have ranged from 45 in randomized controlled trials to prevent short-term mortality, to 91 in observational studies (fig. 5, 6).

The addition of endovascular therapy to IV tPA also translated to improved vessel recanalization in our pooled analysis with an overall mTICI $2 \mathrm{~b} / 3$ rate of $70.2 \%$ (TICI $2 \mathrm{~b} / 3$ used in ESCAPE). While previous data on IV tPA showed that it has been historically administered to only $4-7 \%$ of ischemic stroke patients (partly due to a narrow time window of 3-4.5 h), recanalization rates were dismal, ranging from only 13 to 50\% [25]. Furthermore, the proportion of stroke patients receiving IV tPA is also attenuated due to the potential of

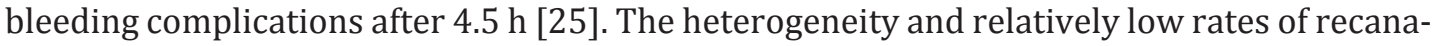
lization were attributed to factors such as a higher clot burden and differences in clot location within the intracerebral circulation [20, 21, 26, 27]. As previously shown, larger thrombi in vessels such as the distal internal carotid artery or proximal middle cerebral artery were less likely to respond to IV tPA [28]. 
The results of these pooled trials were impressive, but it may still be possible for cautious clinicians with memories of prior endovascular studies to question why these trials were so positive. First, it should be mentioned that previous trials used early-generation thrombectomy devices to evaluate recanalization rates as well as safety and efficacy parameters $[16,23,24]$. Devices have improved significantly in design and function over the past 5-10 years, allowing for faster reperfusion rates, higher degree of reperfusion and fewer complications, such as perforations and distal emboli $[15,16,22,28]$.

Even recent trials such as MR RESCUE and IMS 3 were criticized for delayed reperfusion and using older technology, and in the Penumbra pivotal trial, only $25 \%$ of patients had a good 90-day clinical outcome [29]. Similarly, the Merci retriever was assessed in the Multi MERCI trial and showed dismal results of TIMI scores of 2-3 in 68\%, and good clinical outcomes in only $36 \%$ [24]. These older-generation devices have been adequately tested against the newer stent retriever technology in several trials and proven to be inferior with regard to safety profile, recanalization rates, time of puncture to recanalization, and clinical outcomes [8, 30].

Currently the most commonly used stent retriever devices are the Solitaire (ev3) and the Trevo (Concentric Medical) devices. The efficacy of these devices has been established in head-to-head comparisons in multicentered, prospective, randomized controlled trials: SWIFT and Trevo 2, respectively. Both studies established superior recanalization and safety rates with Solitaire and Trevo compared to older generation Merci devices [16, 22, 23, 31, 32].

Another reason why the trials included in this analysis were so positive has to do with their incorporation of image-based patient selection to obtain more information about the relevant vasculature, location of the clot, extent of the core infarct size and salvageable tissue, prior to attempting clot retrieval. Some of the previous trials that attempted to compare endovascular treatment with IV tPA alone randomized patients into the endovascular arm prior to visualizing a LVO. The interventionalists who participated in the 6 MPRCTs pooled in this analysis only attempted clot retrieval when they knew there was a clot to retrieve and that the clot had not yet caused irreversible brain damage. Therefore, they had a significantly greater chance of avoiding futile intra-arterial intervention.

Overall, the trials included in this pooled analysis demonstrated the importance of timely, efficient, effective and safe recanalization of LVO, while avoiding futile intra-arterial recanalization [6]. The results are generalizable to various worldwide populations, since the trials were globally conducted and not just localized to one particular geographical area. The trials were well interspersed geographically to cover major countries and continents (Canada, South Korea, Italy, the Netherlands, Australia, New Zealand, Spain, the United States). However, it should be noted that the proportion of stroke patients who are eligible for endovascular therapy, owing to the strict exclusion criteria, limits generalizability to the entire stroke population as a whole. Further investigation is needed on how endovascular applicability can be enhanced to include a higher ratio of stroke patients and improve overall generalizability.

\section{Conclusion}

It is evident from the results of the 6 major MPRCTs (MR CLEAN, EXTEND IA, ESCAPE, SWIFT PRIME, REVASCAT and THERAPY) that a redefinition of guidelines and recommendations on LVO-related AIS treatment is warranted. This pooled analysis showed that fast and effective endovascular reperfusion along with IV tPA in appropriately selected patients with small to moderate ischemic core volume, and significantly salvageable brain tissue leads to better functional independence at 90 days when compared with IV tPA alone. Based on these results, it seems appropriate to suggest that endovascular clot retrieval should be part of the new standard of care for the treatment of ischemic stroke due to LVO. 


\section{Disclosure Statement}

In accordance with the 'Interventional Neurology' policies and procedures and my ethical obligation as a researcher, I am reporting that neither I nor any of my co-authors have any financial and/or business disclosures.

\section{References}

1 Meyers PM, Schumacher HC, Higashida RT, Barnwell SL, Creager MA, Gupta R, McDougall CG, Pandey DK, Sacks D, Wechsler LR; American Heart Association: Indications for the performance of intracranial endovascular neurointerventional procedures: a scientific statement from the American Heart Association Council on Cardiovascular Radiology and Intervention, Stroke Council, Council on Cardiovascular Surgery and Anesthesia, Interdisciplinary Council on Peripheral Vascular Disease, and Interdisciplinary Council on Quality of Care and Outcomes Research. Circulation 2009;119:2235-2249.

2 Langer A, Krucoff MW, Klootwijk P, Simoons ML, Granger CB, Barr A, Califf RM, Armstrong PW: Prognostic significance of ST segment shift early after resolution of ST elevation in patients with myocardial infarction treated with thrombolytic therapy: the GUSTO-I ST Segment Monitoring Substudy. J Am Coll Cardiol 1998;31: 783-789.

3 Grines CL, Browne KF, Marco J, Rothbaum D, Stone GW, O’Keefe J, Overlie P, Donohue B, Chelliah N, Timmis GC, et al: A comparison of immediate angioplasty with thrombolytic therapy for acute myocardial infarction. The Primary Angioplasty in Myocardial Infarction Study Group. N Engl J Med 1993;328:673-679.

4 Weaver WD, Simes RJ, Betriu A, Grines CL, Zijlstra F, Garcia E, Grinfeld L, Gibbons RJ, Ribeiro EE, DeWood MA, Ribichini F: Comparison of primary coronary angioplasty and intravenous thrombolytic therapy for acute myocardial infarction: a quantitative review. JAMA 1997;278:2093-2098.

5 Andersen HR, Nielsen TT, Rasmussen K, Thuesen L, Kelbaek H, Thayssen P, Abildgaard U, Pedersen F, Madsen JK, Grande P, Villadsen AB, Krusell LR, Haghfelt T, Lomholt SE, Vigholt E, Kjaergard HK, Mortensen LS; DANAMI-2 Investigators: A comparison of coronary angioplasty with fibrinolytic therapy in acute myocardial infarction. N Engl J Med 2003;349:733-742.

6 Hacke W: Interventional thrombectomy for major stroke - a step in the right direction. N Engl J Med 2015; 372:76-77.

7 Jauch EC, Saver JL, Adams HP Jr, Bruno A, Connors JJ, Demaerschalk BM, Khatri P, McMullan PW Jr, Qureshi AI, Rosenfield K, Scott PA, Summers DR, Wang DZ, Wintermark M, Yonas H; American Heart Association Stroke Council; Council on Cardiovascular Nursing; Council on Peripheral Vascular Disease; Council on Clinical Cardiology: Guidelines for the early management of patients with acute ischemic stroke: a guideline for healthcare professionals from the American Heart Association/American Stroke Association. Stroke 2013;44:870-947.

8 Singh B, Parsaik AK, MD, Prokop LJ, Mittal MK: Endovascular therapy for acute ischemic stroke: a systematic review and meta-analysis. Mayo Clin Proc 2013;88:1056-1065.

9 Berkhemer OA, FransenPS, Beumer D, et al: A randomized trial of intraarterial treatment for acute ischemic stroke. N Engl J Med 2015;372:11-20.

10 Goyal M, Demchuk AM, Menon BK, et al: Randomized assessment of rapid endovascular treatment of ischemic stroke. N Engl J Med 2015;372:1019-1030.

11 Saver JL, Goyal M, Bonafe A, Diener HC, Levy EI, Pereira VM, Albers GW, Cognard C, Cohen DJ, Hacke W, Jansen O, Jovin TG, Mattle HP, Nogueira RG, Siddiqui AH, Yavagal DR, Baxter BW, Devlin TG, Lopes DK, Reddy VK, du Mesnil de Rochemont RD, Singer OC, Jahan R; SWIFT PRIME Investigators: Stent-retriever thrombectomy after intravenous t-PA vs. t-PA alone in stroke. N Engl J Med 2015;372:2285-2295.

12 Campbell BC, Mitchell PJ, Kleinig TJ, Dewey HM, Churilov L, Yassi N, Yan B, Dowling RJ, Parsons MW, Oxley TJ, Wu TY, Brooks M, Simpson MA, Miteff F, Levi CR, Krause M, Harrington TJ, Faulder KC, Steinfort BS, Priglinger M, Ang T, Scroop R, Barber PA, McGuinness B, Wijeratne T, Phan TG, Chong W, Chandra RV, Bladin CF, Badve M, Rice H, de Villiers L, Ma H, Desmond PM, Donnan GA, Davis SM; EXTEND-IA Investigators: Endovascular therapy for ischemic stroke with perfusion-imaging selection. N Engl J Med 2015;372:1009-1018.

13 Jovin TG, Chamorro A, Cobo E, de Miquel MA, Molina CA, Rovira A, Román LS, Serena J, Abilleira S, Ribó M, Millán M, Urra X, Cardona P, López-Cancio E, Tomasello A, Castaño C, Blasco J, Aja L, Dorado L, Quesada H, Rubiera M, Hernandez-Pérez M, Goyal M, Demchuk AM, von Kummer R, Gallofré M, Dávalos A; REVASCAT Trial Investigators: Thrombectomy within 8 hours after symptom onset in ischemic stroke. N Engl J Med 2015;372: 2296-2306.

14 Mocco J, Zaidat O, Von Kummer R, Yoo A, Gupta R, Lopes D, Frei D, Khatri P: Therapy trial. ESO Conference, Glasgow, 2015.

15 Lee M, Hong KS, Saver JL: Efficacy of intra-arterial fibrinolysis for acute ischemic stroke: meta-analysis of randomized controlled trials. Stroke 2010;41:932-937.

16 Saver JL, Jahan R, Levy EI, Jovin TG, Baxter B, Nogueira RG, Clark W, Budzik R, Zaidat OO; SWIFT Trialists: Solitaire flow restoration device versus the Merci Retriever in patients with acute ischaemic stroke (SWIFT): a randomised, parallel-group, non-inferiority trial. Lancet 2012;380:1241-1249. 
17 Suh SH, Cloft HJ, Fugate JE, Rabinstein AA, Liebeskind DS, Kallmes DF: Clarifying differences among thrombolysis in cerebral infarction scale variants: is the artery half open or half closed? Stroke 2013;44:1166-1168.

18 Keeley EC, Boura JA, Grines CL: Primary angioplasty versus intravenous thrombolytic therapy for acute myocardial infarction: a quantitative review of 23 randomised trials. Lancet 2003;361:13-20.

19 Huynh T, Perron S, O’Loughlin J, Joseph L, Labrecque M, Tu JV, Théroux P: Comparison of primary percutaneous coronary intervention and fibrinolytic therapy in ST-segment-elevation myocardial infarction: bayesian hierarchical meta-analyses of randomized controlled trials and observational studies. Circulation 2009;119: 3101-3109.

20 National Institute of Neurological Disorders and Stroke rt-PA Stroke Study Group: Tissue plasminogen activator for acute ischemic stroke. N Engl J Med 1995;333:1581-1587.

21 Kleindorfer DO, Broderick JP, Khoury J, Flaherty ML, Woo D, Alwell K, Moomaw CJ, Pancioli A, Jauch E, Miller R, Kissela BM: Emergency department arrival times after acute ischemic stroke during the 1990s. Neurocrit Care 2007; 7:31-35.

22 Nogueira RG, Lutsep HL, Gupta R, Jovin TG, Albers GW, Walker GA, Liebeskind DS, Smith WS; TREVO 2 Trialists: Trevo versus Merci retrievers for thrombectomy revascularisation of large vessel occlusions in acute ischaemic stroke (TREVO 2): a randomised trial. Lancet 2012;380:1231-1240.

23 Barber PA, Demchuk AM, Zhang J, Buchan AM: Validity and reliability of a quantitative computed tomography score in predicting outcome of hyperacute stroke before thrombolytic therapy. ASPECTS Study Group. Alberta Stroke Programme Early CT Score. Lancet 2000;355:1670-1674.

24 Smith WS, Sung G, Saver J, Budzik R, Duckwiler G, Liebeskind DS, Lutsep HL, Rymer MM, Higashida RT, Starkman S, Gobin YP; Multi MERCI Investigators, Frei D, Grobelny T, Hellinger F, Huddle D, Kidwell C, Koroshetz W, Marks M, Nesbit G, Silverman IE: Mechanical thrombectomy for acute ischemic stroke: final results of the Multi MERCI trial. Stroke 2008;39:1205-1212.

25 Schwamm LH, Ali SF, Reeves MJ, Smith EE, Saver JL, Messe S, Bhatt DL, Grau-Sepulveda MV, Peterson ED, Fonarow GC: Temporal trends in patient characteristics and treatment with intravenous thrombolysis among acute ischemic stroke patients at Get With The Guidelines-Stroke hospitals. Circ Cardiovasc Qual Outcomes 2013;6:543-549.

26 Rha JH, Saver JL: The impact of recanalization on ischemic stroke outcome: a meta-analysis. Stroke 2007;38: 967-973.

27 Bhatia R, Hill MD, Shobha N, Menon B, Bal S, Kochar P, Watson T, Goyal M, Demchuk AM: Low rates of acute recanalization with intravenous recombinant tissue plasminogen activator in ischemic stroke: real-world experience and a call for action. Stroke 2010;41:2254-2258.

28 Riedel CH, Zimmermann P, Jensen-Kondering U, Stingele R, Deuschl G, Jansen O: The importance of size: successful recanalization by intravenous thrombolysis in acute anterior stroke depends on thrombus length. Stroke 2011;42:1775-1777.

29 Penumbra Pivotal Stroke Trial Investigators: The penumbra pivotal stroke trial: safety and effectiveness of a new generation of mechanical devices for clot removal in intracranial large vessel occlusive disease. Stroke 2009;40:2761-2768.

30 Van Swieten JC, Koudstaal PJ, Visser MC, Schouten HJ, Van Gijn J: Interobserver agreement for the assessment of handicap in stroke patients. Stroke 1988;19:604-607.

31 Jovin TG, Yonas H, Gebel JM, Kanal E, Chang YF, Grahovac SZ, Goldstein S, Wechsler LR: The cortical ischemic core and not the consistently present penumbra is a determinant of clinical outcome in acute middle cerebral artery occlusion. Stroke 2003;34:2426-2433.

32 Thomalla GJ, Kucinski T, Schoder V, Fiehler J, Knab R, Zeumer H, Weiller C, Röther J: Prediction of malignant middle cerebral artery infarction by early perfusion- and diffusion-weighted magnetic resonance imaging. Stroke 2003;34:1892-1899. 